\title{
WAVELLITE FROM KITTILÄ, FINNISH LAPLAND
}

\author{
KAARLO MäKel ̈̈ \\ Rautaruukki Co., Oulu, Finland
}

\begin{abstract}
Wavellite is a phosphate mineral, not previously on record in Finland. It was found in narrow dikes cutting quartzite on Kätkätunturi hill in the parish of Kittilä, Finnish Lapland. The mode of occurrence of wavellite is described. Optical and X-ray powder method studies and a partial analysis were carried out. Some aspects are presented of the origin and age of the wavellite.
\end{abstract}

\section{Introduction}

The author took part in the geological field work of the Outokumpu Company in the parish of Kittilä, Finnish Lapland, in the summer of 1967. In connection with the geological mapping a small quartzite outcrop was found in which some narrow dikes were seen. The outcrop is situated about half way up the steep eastern slope of the Kätkätunturi hill, and a few tens of meters west of the road from Immelpirtti to the village of Sirkka. Some white radiate crystal accumulations among grey quartz and black hematite were observed in a slab split along the dike (Fig. 1). In the field the mineral was thought to be a kind of zeolite, and only a small sample of the rock was taken for more detailed determinations. In the laboratory, however, the mineral proved to be wavellite, a hydrated basic phosphate of aluminum - $\mathrm{Al}_{6}(\mathrm{~F}, \mathrm{OH})_{6}\left(\mathrm{PO}_{4}\right)_{4} \cdot 9 \mathrm{H}_{2} \mathrm{O}-$ not known to be previously identified in Finland.

\section{Petrography}

The quartzite of Kätkätunturi hill is mainly arcosic and sericite bearing, medium to coarse grained and usually beautifully clastic. Narrow quartz-bearing dikes are often seen to cut the quartzite. Hematite is usually also found in these dikes.

The wavellite-bearing dikes are some $0.5-2$ $\mathrm{cm}$ broad. The contacts of these dikes towards quartzite are commonly fairly sharp, although weak recrystallization of the quartzite near the contacts has sometimes made the contacts less clear. In thin section, the recrystallized zone is seen to be some 1 to $3 \mathrm{~mm}$ broad. Wavellite occurs among quartz and hematite as pure white spherulites, the diameters of which are up to 5 $\mathrm{mm}$. Also fine-grained mass-like wavellite is seen between the spherulites. The volumetric amount of wavellite in the dikes is around $25 \%$. Wavellite greatly resembles some zeolites in outward appearence. 


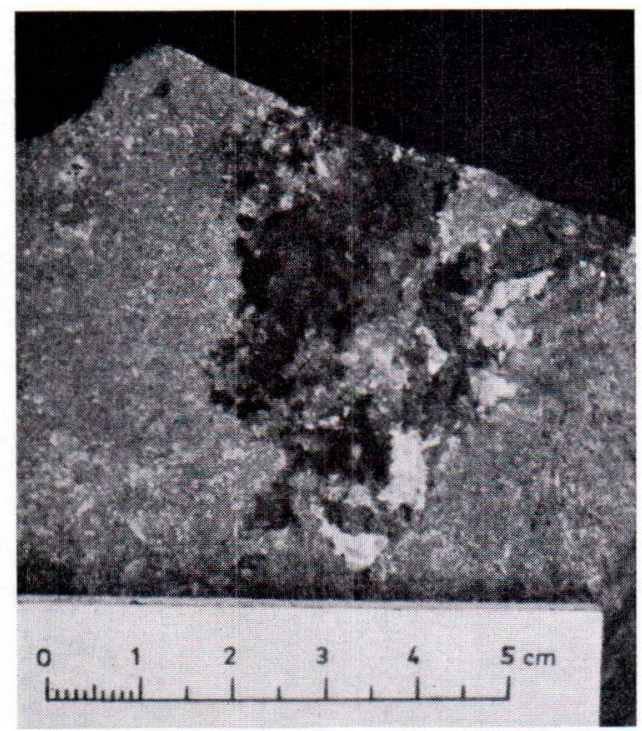

Fig. 1. Wavellite (White) among quartz (grey) and hematite (black) in a dike in quartzite. The slab is partly split the dike. along

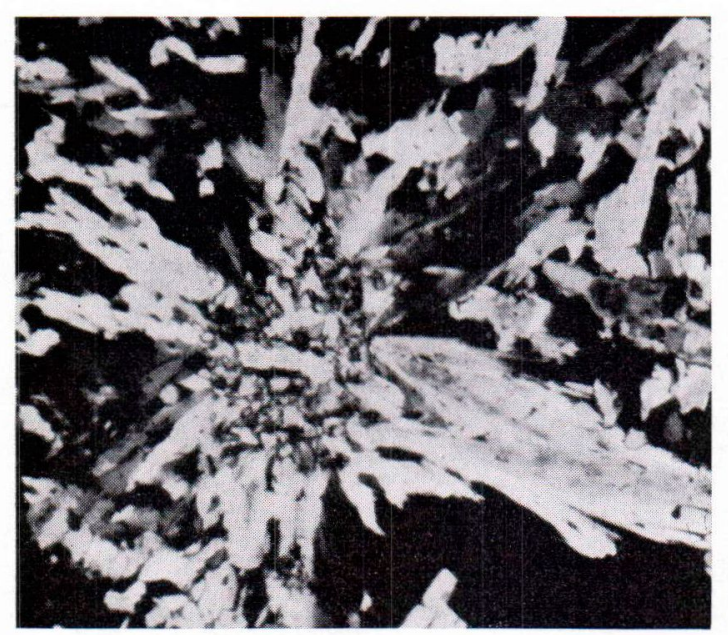

Fig. 2. Wavellite spherulite. Crossed Nicols, magn. $56 \times$.

Microscopically wavellite is easily distinguished from zeolites owing to its higher interference colour and higher refractive indices. Some of its other optical properties also deviate from those of zeolites.

Under the microscope, wavellite occurs as spherulites of colourless splinter-like needles gathered together. Fine- grained wavellite is seen between the spherulites (Fig. 2). The wavellite is colourless also in thicker plates.

The refractive indices of the wavellite were determined by the immersion method in yellow light. They are presented in Table 1, column 1.

Preuss and von Gliszczynski (1950) have examined wavellites from different localities, mainly from Central Europe. Some of these wavellites contain up to $1 \% \mathrm{BeO}$. The authors cited found that the Be-content has no effect on the refractive indices of the wavellites: $\mathrm{n}_{\mathrm{x}} \sim \mathrm{n}_{\mathrm{y}}=1.528 \pm$ 0.005 , and $\mathrm{n}_{\mathrm{z}}=1.551 \pm 0.002$.

Optically, wavellite is positive with $\mathrm{Z}$ parallel to the crystallographic c-axis. The crystal system of wavellite is orthorombic.

$2 \mathrm{~V}_{\mathrm{z}}$ of wavellite from Kittilä was determined on a U-stage as $79 \pm 2^{\circ}$.

Clear growth layers can be seen in the wavellite spherulites (Fig. 3). The fine-grained center of the spherulite is a crystallization center around which the individual needle-like crystals grow, the crystallographic c-axis being as the elongation axis. Similar kinds of growth layers have been described by Doladugina and Berezina (1968) in synthetic corundum crystals.

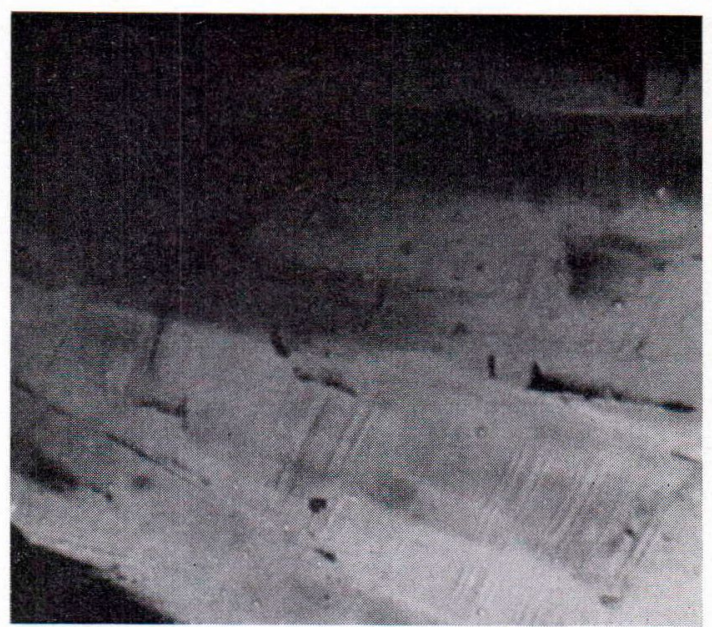

Fig. 3. A part of a wavellite spherulite with concentric growth layers. Center of spherulite on the left. One Nicol, magn. $320 \times$. 
TABLE 1.

Refractive indices of wavellites.

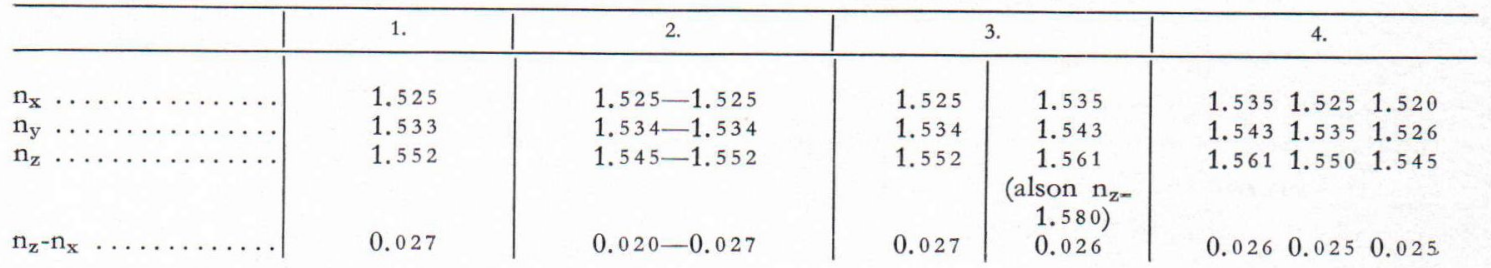

1. Wavellite from Kittilä.

2. Wavellites, cited in Tröger (1959).

3. " " Winchell \& Winchell (1961).

4. " » Palache et al. (1960).

\section{X-ray powder method study}

The powder patterns for wavellite from Kittilä were recorded with a Debye-Scherrer camera (diameter $114.6 \mathrm{~mm}$ ) using Ni-filtered $\mathrm{CuK}_{\alpha}$ radiation (wave length $1.5418 \AA$ ). The small amount of wavellite available did not allow for more complete $\mathrm{X}$-ray studies. The results of the powder method study are presented in Table 2, column 1 . The intensities in column 1 were estimated visually. By comparison, the d-values for a wavellite given by Mihejev (1957) are also presented.

\section{Chemistry}

The following percentages for wavellite from Kittilä were obtained as the averages of five electron probe microanalyser determinations for each element:

$$
\begin{array}{lr}
\mathrm{Al} \ldots \ldots \ldots & 20.0 \% \\
\mathrm{P} \ldots \ldots \ldots & 15.2 \% \\
\mathrm{Fe} \ldots \ldots \ldots & 0.5 \%
\end{array}
$$

The accuracy of these determinations is \pm 0.2 $0.4 \%$ for $\mathrm{Al}$ and $\mathrm{P}$, and $\pm 0.03 \%$ for $\mathrm{Fe}$. Excluding a faint trace of $\mathrm{Cr}$ the wavellite does not contain observable amounts of other elements heavier than $\mathrm{Na}$. The above analysis corresponds to the oxide percentages presented in Table 3 , column 1. The fluorine content of wavellite was
TABLE 2 .

X-ray powder data for wavellites.

\begin{tabular}{c|r|r|r|r|r|r|r}
\hline \multicolumn{2}{c|}{1.} & \multicolumn{2}{c|}{2.} & \multicolumn{2}{|c}{1.} & \multicolumn{2}{|c}{2.} \\
\cline { 5 - 7 } $\mathrm{d}$ & $\mathrm{I}$ & $\mathrm{d}$ & $\mathrm{I}$ & $\mathrm{d}$ & $\mathrm{I}$ & $\mathrm{d}$ & $\mathrm{I}$ \\
\hline 8.41 & 10 & 8.39 & 10 & 1.607 & 3 & 1.600 & 5 \\
5.64 & 7 & 5.64 & 6 & 1.560 & 2 & 1.555 & 4 \\
5.37 & 3 & - & - & 1.540 & 4 & - & - \\
4.98 & 2 & - & - & 1.518 & 2 & 1.520 & 4 \\
4.84 & 4 & 4.82 & 5 & 1.485 & 4 & 1.480 & 2 \\
4.04 & 3 & 4.03 & 4 & 1.450 & 6 & 1.448 & 5 \\
- & - & 3.79 & 4 & 1.410 & 4 & 1.403 & 4 \\
3.44 & 8 & 3.44 & 8 & 1.397 & 2 & - & - \\
3.21 & 8 & 3.20 & 8 & 1.376 & 2 & 1.373 & 2 \\
3.06 & 3 & 3.05 & 4 & 1.343 & 5 & 1.340 & 6 \\
2.95 & 4 & 2.95 & 6 & 1.310 & 1 & 1.302 & 4 \\
2.79 & 4 & 2.78 & 6 & 1.266 & 2 & 1.261 & 4 \\
2.57 & 7 & 2.56 & 8 & 1.250 & 3 & 1.241 & 4 \\
2.36 & 4 & 2.37 & 4 & 1.230 & 1 & 1.225 & 2 \\
2.26 & 4 & 2.25 & 2 & 1.199 & 2 & 1.197 & 2 \\
2.19 & 2 & 2.19 & 2 & 1.182 & 3 & 1.179 & 4 \\
2.09 & 7 & 2.08 & 6 & 1.161 & 4 & 1.158 & 4 \\
2.04 & 2 & 2.03 & 2 & 1.138 & 1 & 1.141 & 2 \\
1.960 & 6 & 1.951 & 6 & 1.118 & 3 & 1.111 & 4 \\
1.889 & 2 & 1.881 & 4 & - & - & 1.091 & 2 \\
1.824 & 2 & 1.821 & 4 & - & - & 1.079 & 2 \\
1.751 & 3 & 1.749 & 5 & - & - & 1.056 & 2 \\
1.710 & 5 & 1.704 & 4 & - & - & 1.045 & 4 \\
1.670 & 4 & 1.664 & 2 & - & - & 1.023 & 2 \\
1.647 & 1 & -1.003 & - & -1 & - & 1.003 & 2 \\
& & & & & &
\end{tabular}

1. Wavellite from Kittilä.

2. Wavellite (Mihejev 1957, p. 631).

determined in the Central Laboratory of the Outokumpu Company at Pori as $2.7 \%$ from the wavellite powder purified with a Frantz isodynamic magnetic separator. The water content was counted by subtracting the fluorine percentage from the loss on ignition of wavellite 
powder which was $30.1 \%$. The percentage of water thus obtained is clearly too high (27.4\%); according to the total sum of Table 3 , column 1 , the wavellite must have contained some $2 \%$ nonessential capillary water. The hygroscopic nature of the powdered wavellite was proved by another water determination made from the same wavellite powder 8 moths after the first one. The total water content of wavellite was then obtained as $30.0 \%$.

The composition of the wavellite from Kittilä can be seen to correspond rather to the formula $\mathrm{Al}_{6}(\mathrm{~F}, \mathrm{OH})_{6}\left(\mathrm{PO}_{4}\right)_{4} \cdot 9 \mathrm{H}_{2} \mathrm{O}$ - as given in Winchell \& Winchell (1961) - than to $\mathrm{Al}_{3}(\mathrm{OH})_{3}$ $\left(\mathrm{PO}_{4}\right)_{2} \cdot 5 \mathrm{H}_{2} \mathrm{O}$, the formula given for wavellite in Palache et al. (1960).

TABLE 3.

Analyses of wavellites.

\begin{tabular}{|c|c|c|c|c|c|c|c|}
\hline & 1. & 2. & 3. & 4. & 5 a. & $5 \mathrm{~b}$. & $5 \mathrm{c}$. \\
\hline 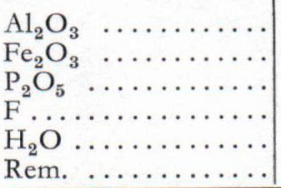 & $\begin{array}{r}37.8 \\
0.7 \\
34.8 \\
2.7 \\
27.4 \\
\end{array}$ & $\begin{array}{r}37.1 \\
34.5 \\
28.4 \\
-\end{array}$ & $\begin{array}{r}38.0 \\
35.2 \\
26.8 \\
-\end{array}$ & $\begin{array}{r}33.3 \\
0.2 \\
33.0 \\
0.93 \\
- \\
\end{array}$ & $\begin{array}{r}31.01 \\
3.18 \\
32.72 \\
0.60 \\
27.92 \\
5.17\end{array}$ & $\begin{array}{r}37.44 \\
0.64 \\
33.40 \\
2.79 \\
26.45 \\
\end{array}$ & $\begin{array}{r}35.77 \\
0.30 \\
33.65 \\
2.05 \\
27.45 \\
1.40\end{array}$ \\
\hline $\mathrm{F}=\mathrm{O} \ldots \ldots \ldots \ldots$ & $\begin{array}{r}103.4 \\
1.1\end{array}$ & 100.0 & $\begin{array}{r}100.0 \\
-\end{array}$ & - & $\begin{array}{r}100.60 \\
0.25\end{array}$ & $\begin{array}{r}100.72 \\
1.17\end{array}$ & $\begin{array}{r}100.64 \\
0.86\end{array}$ \\
\hline Total & 102.3 & - & - & - & 100.35 & 99.55 & 99.78 \\
\hline
\end{tabular}

1. Wavellite from Kittilä.

2. Theoretical composition of wavellite according to the formula $\mathrm{Al}_{3}(\mathrm{OH})_{3}\left(\mathrm{PO}_{4}\right)_{2} \cdot 5 \mathrm{H}_{2} \mathrm{O}$.

3. Theoretical composition of wavellite according to the formula $\mathrm{Al}_{6}(\mathrm{OH})_{6}\left(\mathrm{PO}_{4}\right)_{4} \cdot 9 \mathrm{H}_{2} \mathrm{O}$.

\section{Discussion}

The quartzite of Kätkätunturi belongs to what Mikkola (1941) called the Kumpu-Oraniemi sedimentary series, or to the Sirkka formation of the molasse facies of the Karelian orogeny according to the present author ( $c f$. Mäkelä 1968). The Sirkka formation was slightly folded by the last orogenic pulses and it represents a fairly high tectonic level; hence the rocks of this formation have been at a rather rigid stage. In addition, the shear zone of the deep valley of Immeljärvi (Mikkola 1941, p. 117) is quite near to the place where the wavellite was found. In an environment like this there have been opportunities for the opening of fissures into which the telemagmatic fluids of the late orogenic magmatism (»spätorogen», in the sense of Stille 1939) could have intruded very easily.
4. Wavellite from Florida, U.S.A. (Bergendahl 1955).

5. Wavellites, cited in Palache et al. (1960).

a. Wavellite from Černovice, Bohemia.

b. » » Clonmel, Ireland.

c. » $\gg$ Llallagua, Bolivia.

Narrow dikes filling fissures are often seen in the quartzites of the Sirkka formation. In these dikes, quartz and hematite are the main constituents. Carbonates, magnetite, chalcopyrite and chalcosite are more rarely found in them. Wavellite was only found in one place. However, since wavellite was not especially expected, it is possible that it often remained unnoticed in the dikes, due to its simple outward appearence.

An age of appr. $1800 \mathrm{My}$ is generally accepted for the Karelian orogeny in Lapland. Wavellitebearing dikes belong to the latest crystallizations of the late orogenic fluids of this orogeny. Because there is no evidence against a primary hydrothermal origin of the wavellite from Kittilä, the age of this mineral must also be appr. 1 $800 \mathrm{My}$.

Acknowledgements - The author wishes to thank Professor Pavo Haapala, Ph. D., for the permission to 
publish the present paper, and Dr. T. A. Häkli, for the analyses. Both of these gentlemen are from the Outokumpu Company. He also wishes to express his gratitude to Professor Juhani Seitsaari, Ph. D., head of the Depart- ment of Geology, University of Oulu, for his kind permission to use the instruments of the Department of Geology, for reading the manuscript and for giving valuable advice and criticism.

\section{REFERENCES}

Bergendahl, M. H. (1955) Wavellite Spherulites in the Bone Valley Formation of Central Florida. The American Mineralogist. Vol. 40, pp. 497-504.

Doladugina, V. S. and Berezina, E. E. (1968) Examination of Corundum for Homogeneity with a Polarizing Shadow System. In Sheftal', N. N. (editor) Growth of Crystals. Volume 5 B, pp. 177-168. New York

Minejev, V. I. (1957)

Михеев, В.И. (1957) Рентгенометрический определитель минералов. Москва.

Mikkola, Erkki (1941) The General Geological Map of Finland. Sheets B 7-C 7-D 7, Muonio-Sodankylä-Tuntsajoki. Explanation to the Map of Rocks. Geological Survey of Finland.

MÄKEL ̈̈, KAARLO (1968) Sirkka-muodostumasta ja stratigrafian yleispiirteistä Keski-Lapin liuskealueella. Licentiate thesis. Manuscript in the archives of the Department of Geology, University of Oulu, Finland. Palache, Charles, Berman, Harry and Frondel, Clifford (1960) Dana's System of Mineralogy. Volume II, seventh edition. New York.

Preuss, E. and von Gliszczynski, S. (1950) Über den Berylliumgehalt einiger Wavellite. Geochimica et Cosmochimica Acta. Vol. 1, pp. 86-88.

Stille, Hans (1939) Zur Frage der Herkunft der Magmen. Abh. d. Preuss. Akad. d. Wiss., Math.-natur-wiss. Kl., 19. Berlin.

Tröger, W. E. (1959) Optische Bestimmung der gesteinbildenden Minerale. Teil 1. Stuttgart.

Winchell, A. N. \& Winchell, H. (1961) Elements of Optical Mineralogy. Part II. New York.

Manuscript received, January 29, 1969. 